\title{
Report
}

\section{Kleine Schritte auf dem Weg zur EU-Datenschutzverordnung}

In Brüssel fand am 06.06.2014 das Justice-Council der Justiz- und Innenminister der EU-Mitgliedsstaaten statt. Auf der Tagesordnung standen auch - auf Grundlage von Vorschlägen des Griechischen Justizministers (im Rahmen der Ratspräsidentschaft) - zwei Themen der EU-Datenschutzverordnung.

Dazu heißt es im Kommuniqué des Council's:

\section{Data protection}

The Council reached a partial general approach on specific aspects of the draft regulation setting out a general EU framework for data protection. The partial general approach includes the provisions on territorial scope, the respective definitions of "binding corporate rules" and "international organisations", and the transfer of personal data to third countries or international organisations.

The Council also held a policy debate on the "one-stop-shop" mechanism on the basis of a document prepared by the Presidency. The incoming Council Presidency will continue work at technical level on this issue. Charalambos ATHA5ASIOU, Greek Minister for Justice, Transparency and Human Rights and President of the Council said: "We have devoted a lot of effort to this proposal. Sufficient progress has been made to support a partial general approach. Today's agreement constitutes a good basis for future work".

Der Europäische Datenschutzbeauftragte - Peter Hustinxs - appellierte auf dieser Grundlage:

EDPS calls on the Council to make urgent progress on Data Protection Reform

The European Data Protection Supervisor (EDPS) fully appreciates the progress made by the Greek Presidency of the Council on the reform of the EU Data Protection legislation. In particular, we welcome the Council's objective of reaching a general position on the package so as to start negotiations with the Parliament well before the end of 2014. Articles 7 and 8 of the Charter of Fundamental Rights of the EU provide for the protection of the rights of everyone in the $\mathrm{EU}$ and the proposed data protection reform is vital in safeguarding these.

However, despite some progress, there are still a number of issues for which solutions must be found. The EDPS urges the Council to make substantive progress on these issues as soon as possible and encourages it not to weaken what is currently a robust and comprehensive proposal for a Regulation. In addition, the Council must ensure that the Regulation remains inclusive of the public sector, furthers the harmonisation and consistency of EU data protection through the one-stop-shop principle and introduces the principle of accountability and instruments for stronger enforcement in order to better ensure compliance with the legislation. Finally, progress should also be made with regard to the proposed Directive on data protection, in the context of criminal law enforcement.
The EDPS considers it imperative that EU rules on data protection are reformed urgently, not only to provide more consistency and uniformity in data protection across the EU, but most of all to ensure that the fundamental rights to privacy and data protection of all individuals in the EU are effectively protected. EU citizens are more aware than ever of the importance of their personal data, and increasingly skeptical of the ability of governments to protect them. The Council must act now and it must act boldly to restore public trust in EU data protection policy.

EDPS - The European guardian of data protection www.edps.europa.eu

\section{Nachfolger für Verschlüsselungssoftware TrueCrypt}

Als Reaktion auf das aktuell bekannt gegebene Ende der Weiterentwicklung der Verschlüsselungs-software TrueCrypt durch das bisherige Entwickler-Team plant die Sirrix AG, Saarbrücken (https:// www.sirrix.de/content/pages/home.htm), mit der Software TrustedDisk eine erweiterte Version von TrueCrypt zu veröffentlichen und als Open-Source-Lösung weiterzuentwickeln.

Bereits vor drei Jahren hatte die Sirrix AG gemeinsam mit der escrypt $\mathrm{GmbH}$ im Auftrag des Bundesamtes für Sicherheit in der Informationstechnik (BSI) TrueCrypt einem umfassenden Audit unterzogen. Die im Audit gesammelten Erkenntnisse sind in die neue Verschlüsselungssoftware eingeflossen und haben die bisherige TrueCrypt-Sicherheits-Architektur und-Implementierung deutlich verbessert. Hierzu gehören beispielsweise ein verbesserter Bootloader, die Zufallszahlenerzeugung oder der Schutz des Schlüsselmaterials.

„Mit einem Open-Source Nachfolger für TrueCrypt wollen wir sicherstellen, dass auch Privatanwendern in Zukunft eine vertrauenswürdige Verschlüsselungslösung mit einem hohen Sicherheitsniveau bereitsteht", so Sirrix-Vorstandschef Ammar Alkassar. „Angesicht des Jahrestages der Snowden-Enthüllungen erscheint die Empfehlung der bisherigen TrueCrypt-Entwickler, auf Microsofts Bitlocker zu wechseln, unverständlich“, kommentiert Alkassar.

Die Sirrix AG bietet mit TrustedDisk Enterprise bereits jetzt eine Lösung zur Festplattenverschlüsselung (Full-Disk Encryption) an, deren Funktionalität deutlich über die der Open-Source-Lösung TrueCrypt hinausgeht. Hierzu gehören Public-Key Kryptographie zur effizienten Schlüsselverwaltung, SmartCard-Unterstützung und ein zentrales Management mit eigener PKI. TrustedDisk wurde 2012 durch das BSI für die behördliche Verarbeitung von Daten, die als VS- Verschlusssache-NUR FÜR DEN DIENSTGEBRAUCH eingestuft sind, zugelassen und wird in Bundes- und Landesverwaltungen sowie bei Unternehmen in Deutschland, insbesondere, die einer Sicherheitsbetreuung unterliegen, breit eingesetzt.

Die Verschlüsselung von Festplatten und anderen Datenträgern leistet einen wichtigen Beitrag zum Schutz vor Wirtschaftsspiona- 